\title{
Liver function tests in chronic viral hepatitis cases
}

\author{
Kronik viral hepatit olgularında karaciğer fonksiyon testleri
}

Goncagül HAKLAR

\begin{abstract}
The liver has many vital functions and biochemical tests are used for the assessment. For the diagnosis of chronic hepatitis: (1) persistence of increased alanine aminotransferase (ALT) for 6 months after an episode of acute hepatitis; or (2) increased ALT (without another explanation) on more than one occasion over a period of 6 months are needed. The time period may be shorter for the patients with risk factors. Although the clinical picture of HBV and $\mathrm{HCV}$ in chronic cases is similar, aminotransferase activities are different. In HBV, ALT activity is generally constant, except increases are evident at seroconversion times. On the other hand, two-third of $\mathrm{HCV}$ cases experience fluctuation. In the evaluation of a patient with a new diagnosis of chronic viral hepatitis, a comprehensive medical history should be taken, followed by full physical examination. Laboratory workup should start with a comprehensive metabolic panel with liver function tests including assessment of synthetic function with prothrombin time and serum albumin level measurement. Screening for the chronic hepatic injury is not cost-effective and should be limited to high-risk individuals. ALT should be the preferred biochemistry parameter besides viral serology and increased activity should be confirmed before further evaluation. For treatment, patients with increased ALT are more likely to respond than those with initially normal ALT activity.
\end{abstract}

Keywords: Chronic viral hepatitis, Hepatitis B virus, Hepatitis C virus, Alanine aminotransferase, Aspartate aminotransferase

Goncagül Haklar (凶)

Department of Biochemistry, School of Medicine, Marmara University and Marmara University Pendik Education and Research Hospital, Biochemistry Laboratory, Istanbul, Turkey

e-mail:drhaklar@superonline.com
ÖZ

Karaciğerin pek çok hayati fonksiyonu vardır ve bu fonksiyonlar biyokimya testleri ile değerlendirilir. Kronik viral hepatit tanısı için: (1) akut hepatit atağından sonra 6 ay boyunca yüksek seyreden alanin aminotransferaz (ALT) aktivitesi; veya herhangi bir neden olmaksızın 6 ay içinde bir kereden fazla ALT yüksekliği gereklidir. Risk gruplarında süre kısaltılabilir. Kronik olgularda HBV ve HCV benzer klinik tablolar sergileseler de, aminotransferaz aktiviteleri farklıdır. HBV olgularında ALT aktivitesi genelde sabitken, serokonversiyon dönemlerinde artışlar izlenir. HCV olgularının üçte ikisinde ise dalgalanmalar olur. Yeni tanı almış kronik viral hepatit olgularında ayrıntılı tıbbi öykü alınmalı ve ayrıntılı fizik muayene yapılmalıdır. Laboratuvar incelemeleri karaciğer fonksiyon testleri ve protrombin zamanı ile serum albümin düzeyi ölçümleri gibi karaciğerin sentez fonksiyonlarını da değerlendiren testleri de içeren ayrıntılı bir metabolik panel ile başlamalıdır. Kronik viral hepatit taraması maliyet-etkin değildir ve sadece yüksek risk taşıyanlar ile sınırlı olmalıdır. Viral serolojinin yanı sıra biyokimya testi olarak ALT tercih edilmeli, artmış aktivite ileri incelemeden önce mutlaka teyid edilmelidir. Tedavi izleminde artmış ALT aktivitesi olan olgular başlangıçta normal olanlara göre daha iyi cevap verirler.

Anahtar kelimeler: Kronik viral hepatit, Hepatit B virüsü, Hepatit $\mathrm{C}$ virüsü, Alanin aminotransferaz, Aspartat aminotransferaz

\section{Introduction}

The liver has many vital biochemical functions including excretion, synthesis, metabolism, and storage. Endogenous and exogenous organic anions are extracted, biotransformed, and excreted into the bile, while the measurement of endogenously produced compounds like bilirubin and bile acids are used for the assessment of excretory function. Hepatic synthetic function not only involves glucose synthesis via gluconeogenesis, but also protein, triglyceride, fatty acid, cholesterol, and bile acid synthesis as well. Activation and detoxification of drugs, and the disposal of exogenous and endogenous substances, such as galactose and ammonia are included in hepatic metabolic functions. 
Liver is the major site for glycogen storage besides some minerals and vitamins. Liver function tests are useful in (1) detecting, (2) diagnosing, (3) evaluating severity, (4) monitoring therapy, and (5) assessing the prognosis of liver disease and dysfunction. Different tests are utilized to assess different functions of the liver (Table I) [1].

Table I. Main liver function tests and their usage

\begin{tabular}{ll}
\hline Test & Usage \\
\hline Bilirubin, total & $\begin{array}{l}\text { Diagnosing jaundice, modest correlation } \\
\text { with severity }\end{array}$ \\
$\begin{array}{l}\text { Alkaline phosphatase } \\
\text { (ALP) }\end{array}$ & $\begin{array}{l}\text { Diagnosing disorders of metabolism in } \\
\text { children, cholestatic disorders in adults }\end{array}$ \\
$\begin{array}{l}\text { Bilirubin, direct and } \\
\text { indirect }\end{array}$ & $\begin{array}{l}\text { Diagnosing cholestasis and space- } \\
\text { occupying lesions }\end{array}$ \\
$\begin{array}{l}\text { Aspartate } \\
\text { aminotransferase } \\
\text { (AST) }\end{array}$ & $\begin{array}{l}\text { Sensitive test of hepatobiliary disease; } \\
\text { AST>ALT in alcoholic disease }\end{array}$ \\
$\begin{array}{l}\text { Alanine } \\
\text { aminotransferase }\end{array}$ & $\begin{array}{l}\text { Sensitive and more specific test of } \\
\text { hepatobiliary disease }\end{array}$ \\
Albumin & Indicator of chronicity and severity \\
Prothrombin time & $\begin{array}{l}\text { Derangement of synthetic functions } \\
\text { in acute cases, indicator of severity of } \\
\text { (PT) }\end{array}$
\end{tabular}

Chronic hepatitis is defined as a chronic inflammation of the liver that persist for at least 6 months, or signs and symptoms of chronic liver disease in the presence of elevated cytosolic enzymes [2]. The clinical presentations of chronic hepatitis cases are highly variable. Most patients are diagnosed because of unexplained abnormalities of aminotransferases or positive results on screening tests for cause of chronic hepatitis. Moderate elevations of aminotransferase activities (twofold to fivefold) are characteristic, whereas results of most other tests are normal. Normal aminotransferase activities do not rule out pathological evidence of chronic hepatitis, especially in the presence of chronic viral hepatitis or nonalcoholic steatohepatitis [3,4].

'National Academy of Clinical Biochemistry Guidelines on Use of Laboratory Tests in the Diagnosis and Monitoring of Hepatic Injury' states that in the absence of liver biopsy showing evidence of chronic hepatitis, one of the following laboratory results should be used for the diagnosis of chronic hepatitis: (1) persistence of increased alanine aminotransferase (ALT; EC 2.6.1.2) for 6 months after an episode of acute hepatitis; or (2) increased ALT (without another explanation) on more than one occasion over a period of 6 months. In patients with risk factors for chronic viral hepatitis, genetic causes of hepatic injury, autoimmune liver injury, or in the presence of clinical signs or symptoms of liver disease the time period may be shorter (evidence IIB) [2].

Although the clinical picture of $\mathrm{HBV}$ and $\mathrm{HCV}$ in chronic cases is similar, aminotransferase activities are different. In HBV, ALT activity is generally constant, except increases are evident at seroconversion times. On the other hand, twothird of HCV cases experience fluctuation [5-7]. Serum ALT activities of chronic hepatitis $\mathrm{C}$ cases range between one to four times the upper reference limit, reaching maximum less than seven times. On the other hand, $15-50 \%$ of cases with chronic hepatitis $\mathrm{C}$ have normal ALT activities $[6,8,9]$, but this rates decreases with increasing number of measurements [8]. From $43 \%$ of cases experiencing fluctuation between normal and abnormal, $16 \%$ of those with normal ALT on their first two visits and $11 \%$ of those with normal ALT on their first three visits subsequently develop increased ALT [8]. Chronic hepatitis C cases with persistantly normal ALT activities experience lower rates of progression to cirrhosis $[7,10]$. ALT activity is consistently higher than aspartate aminotransferase (AST; EC 2.6.1.1) with all causes of chronic hepatic injury except for alcoholic hepatitis [11-14]. Additionally, ALT may be normal in cirrhotic cases but AST activity increased $[15,16]$. Total bilirubin, direct bilirubin, and alkaline phosphatase (ALP; EC 3.1.3.1) are generally normal in chronic viral hepatitis cases $[17,18]$.

In the evaluation of a patient with a new diagnosis of chronic viral hepatitis, a comprehensive medical history should be taken, followed by full physical examination. Laboratory workup should start with a comprehensive metabolic panel with liver function tests including assessment of synthetic function with prothrombin time and serum albumin level measurements. Although ALT reflects liver inflammation, its correlation with necroinflammation is not satisfactory and even poorer for fibrosis [19,20]. Thrombocytopenia (count $<150000 / \mu \mathrm{L}$ ) is often a sign of portal hypertension and liver cirrhosis, but its sensitivity and specificity is limited for the diagnosis of cirrhosis $(68 \%$ and $76 \%$, respectively) [21]. AST/ALT ratio $>1$ is another laboratory marker suggestive of cirrhosis, which is also seen in alcoholism. Combined tests like AST/platelet ratio index (APRI) and Forn index show good correlation with liver fibrosis [22,23]. Measurement of 25-hydroxy-vitamin D3 level will be beneficial, as its deficiency has been found to be correlated with reduced antiviral activity of peg-interferon plus ribavirin treatment [24-26]. Chronic viral hepatitis cases 
with cirrhosis should be monitored in every 3-6 months with clinical examinations and laboratory tests (comprehensive metabolic panel, coagulation profile, complete blood count) with the calculation of the Child-Turcotte-Pugh (CTP) and Model for End-Stage Liver Disease (MELD) score to determine the prognosis of patient $[27,28]$.

According to 'European Association for the Study of the Liver Disease (EASL 2012)', ALT is considered as a classification criteria for the phases of chronic hepatitis B (CHB): (1) immune tolerant phase with $\mathrm{HBeAg}$ positive, $\mathrm{HBeAb}$ negative, Viral $\mathrm{DNA}>20000 \mathrm{IU} / \mathrm{mL}$ and normal ALT level, (2) HBeAg-positive CHB (immune reactive) phase with $\mathrm{HBeAg}$ positive, $\mathrm{HBeAb}$ negative, Viral DNA $>2000 \mathrm{IU} / \mathrm{mL}$ and elevated ALT level, (3) low replicative phase with $\mathrm{HBeAg}$ negative, $\mathrm{HBeAb}$ positive, Viral DNA $<2000 \mathrm{IU} / \mathrm{mL}$ and normal ALT level, and (4) HBeAgnegative $\mathrm{CHB}$ phase with $\mathrm{HBeAg}$ negative, $\mathrm{HBeAb}$ positive, viral DNA > $2000 \mathrm{IU} / \mathrm{ml}$ and elevated ALT level [29-31].

Screening for the chronic hepatic injury is not costeffective and should be limited to high-risk individuals like anyone who has ever injected illicit drugs, recipients of blood transfusions or solid organ transplants before July 1992, or clotting factor concentrates before 1987, patients who have ever received long-term hemodialysis treatment, persons with known exposure to hepatitis $\mathrm{C}$, persons infected with HIV, children born to HCV-positive mothers, persons with persistently elevated levels of alanine aminotransferase, and anyone born from 1945 through 1965 according to "Centers for Disease Control and Prevention Hepatitis C Virus Testing Recommendations", August 2012 [32-34]. ALT should be the preferred biochemistry parameter besides viral serology and increased activity should be confirmed before further evaluation $[17,18]$. An increase of one to two times the upper reference limit should not be attributed to disease state $[17,18,35]$. Especially in young individuals creatine kinase (CK; EC 2.7.3.2) measurement should be considered to rule out skeletal muscle as the origin besides history of exercise [36]. Generally, chronic HBV carriers have normal ALT activity like many cases of chronic HCV cases but repeated testing increase the chance of revealing increased values [37]. Anti-HCV-positive chronic cases should be confirmed with HCV RNA tests and negative results in the presence of increased ALT activities should be repeated (evidence IIB).

For treatment, patients with increased ALT are more likely to respond than those with initially normal ALT activity $[38,39]$. For HCV treatment HCV RNA levels and ALT activity should be measured after 12 weeks of treatment to determine nonresponders (evidence IIB).

\section{Key Points}

- Liver function tests are useful in detecting, diagnosing, evaluating severity, monitoring therapy of chronic liver diseases.

- Persistence of increased alanine aminotransferase for 6 months after an episode of acute hepatitis indicates chronicity.

- In the treatment of Chronic hepatitis patients with increased ALT are more likely to respond than those with initially normal levels.

\section{References}

1. Burtis CA, Ashwood ER, Bruns D (editors). Tietz Textbook of Clinical Chemistry and Molecular Medicine. St. Louis: Elsevier Saunders, 2006: 1777-847.

2. Dufour D, Lott J, Nolte F, et al. Diagnosis and monitoring of hepatic injury. II. Recommendations for use of laboratory tests in screening, diagnosis, and monitoring. Clin Chem 2000;46:2050-68.

3. Dincer D, Okten A, Kaymakoglu S, et al. Persistantly normal alanine transaminase levels in chronic $\mathrm{C}$ hepatitis: What does it tell us? Hepatogastroenterology 2001;48:1397-400.

4. Mofrad P, Contos M, Haque M, et al. Clinical and histologic spectrum of nonalcoholic fatty liver disease associated with normal ALT values. Hepatology 2003;37:1286-92.

5. Dufour DR. Alanine aminotransferase variation in chronic hepatitis $\mathrm{C}$ infection: An analysis of 357 cases. Clin Chem 2001;47:A26-A7.

6. Alter HJ, Conry-Cantilena C, Melpolder J, et al. Hepatitis C in asymptomatic blood donors. Hepatology 1997;26(Suppl 1):29-33.

7. Mathurin P, Moussalli J, Cadranel J-F, et al. Slow progression rate of fibrosis in hepatitis $\mathrm{C}$ patients with persistently normal alanine aminotransferase activity. Hepatology 1998;27:56872 .

8. Inglesby $\mathrm{TV}$, Rai $\mathrm{R}$, Astemborski $\mathrm{J}$, et al. A prospective community-based evaluation of liver enzymes in individuals with hepatitis C after drug use. Hepatology 1999;29:590-6.

9. Kenny-Walsh E. Clinical outcomes after hepatitis $\mathrm{C}$ infection from contaminated anti-D immune globulin. The Irish Hepatology Research Group. N Engl J Med 1999;340:122833.

10. Hoofnagel JH. Hepatitis C: the clinical spectrum of disease. Hepatology 1997;26(Suppl 1):15-20.

11. Chang C, Ko Y, Liu H. Serum alanine aminotransferase levels in relation to hepatitis $\mathrm{B}$ and $\mathrm{C}$ virus infections among drug abusers in an area hyperendemic for hepatitis B. Dig Dis Sci 2000;45:1949-52.

12. Fontana R, Lok A. Noninvasive monitoring of patients with chronic hepatitis C. Hepatology 2002;36:S57-64.

13. Imperiale $\mathrm{T}$, Said A, Cummings O, Born L. Need for validation of clinical decision aids: Use of the AST/ALT ratio in predicting cirrhosis in chronic hepatitis C. Am J Gastroenterol 2000;95:2328-32.

14. Park G, Lin B, Ngu M, Jones D, Kateralis P. Aspartate 
aminotransferase: alanine aminotransferase ratio in chronic hepatitis $\mathrm{C}$ infection: Is it a useful predictor of cirrhosis? J Gastroenterol Hepatol 2000;15:386-90.

15. Sheth SG, Glamm SL, Gordon FD, Chopra S. AST/ALT ratio predicts cirrhosis in patients with chronic hepatitis $\mathrm{C}$ virus infection. Am J Gastroenterol 1998;93:44-8.

16. Giannini E, Botta F, Fasoli A, et al. Progressive liver functional impairment is associated with an increase in AST/ ALT ratio. Dig Dis Sci 1999;44:1249-53.

17. Friedman LS, Dienstag JL, Watkins E, et al. Evaluation of blood donors with elevated serum alanine aminotransferase levels. Ann Intern Med 1987; 107:137-44.

18. Hay JE, Czaja AJ, Rakela J, Ludwig J. The nature of unexplained chronic aminotransferase elevations of a mild to moderate degree in asymptomatic patients. Hepatology 1989;9:193-7.

19. McCormick SE, Goodman ZD, Maydonovitch CL, Sjogren MH. Evaluation of liver histology, ALT elevation, and HCV RNA titer in patients with chronic hepatitis C. Am J Gastroenterol 1996; 91:1516-22.

20. Gobel T, Erhardt A, Herwig M, et al. High prevalence of significant liver fibrosis and cirrhosis in chronic hepatitis B patients with normal ALT in central Europe. J Med Virol 2011; 83:968-73.

21. Lu SN, Wang JH, Liu SL, et al. Thrombocytopenia as a surrogate for cirrhosis and a marker for the identification of patients at high-risk for hepatocellular carcinoma. Cancer 2006; 107:2212-22.

22. Wai CT, Greenson JK, Fontana RJ, et al. A simple noninvasive index can predict both significant fibrosis and cirrhosis in patients with chronic hepatitis C. Hepatology 2003; 38:518-26.

23. Forns X, Ampurdanes S, Llovet JM, et al. Identification of chronic hepatitis $\mathrm{C}$ patients without hepatic fibrosis by a simple predictive model. Hepatology 2002; 36(4 Pt 1):98692.

24. Bitetto D, Fattovich G, Fabris C, et al. Complementary role of vitamin D deficiency and the interleukin-28B rs 12979860 $\mathrm{C} / \mathrm{T}$ polymorphism in predicting antiviral response in chronic hepatitis C. Hepatology 2011; 53:1118-26.

25. Lange CM, Bojunga J, Ramos-Lopez E, et al. Vitamin D deficiency and a CYP27B1-1260 promoter polymorphism are associated with chronic hepatitis $\mathrm{C}$ and poor response to interferon-alfa based therapy. J Hepatol 2011; 54:887-93.

26. Petta S, Camma C, Scazzone C, et al. Low vitamin D serum level is related to severe fibrosis and low responsiveness to interferon-based therapy in genotype 1 chronic hepatitis $\mathrm{C}$. Hepatology 2010; 51:1158-67.

27. Brau N. Evaluation of the Hepatitis C Virus-Infected Patient: The Initial Encounter. Viral Hepatitis 2013;56:853-60.

28. Kamath PS, Wiesner RH, Malinchoc M, et al. A model to predict survival in patients with end-stage liver disease. Hepatology 2001; 33: 464-70.

29. EASL Clinical Practice Guidelines. Manage- ment of chronic hepatitis B. Association for the Study of the Liver. J Hepatol 2012; 57:167-185.

30. ChanHL, WongGL, WongVW. A review of the natural history of chronic hepatitis B in the era of transient elastography. Antivir Ther 2009;14:489-99.

31. Sharifi Z. Natural history of chronic hepatitis B virus infection based on laboratory testing. Iranian J Publ Health 2014;7:990-3.

32. Recommendations for the identification of chronic hepatitis C virus infection among persons born during 1945-1965. MMWR Recomm Rep 2012; 61(RR-4):1-32.

33. David T Arnold DT, Bentham LM, Jacob RP, Lilford RJ, Girling AJ. Should patients with abnormal liver function tests in primary care be tested for chronic viral hepatitis: cost minimisation analysis based on a comprehensively tested cohort. BMC Family Practice 2011; 12:9-22.

34. Heidelbaugh JJ, Bruderly AM. Cirrhosis and Chronic Liver Failure: Part I. Diagnosis and Evaluation. Am Fam Physician 2006;74: 756-62.

35. Van Ness MM, Diehl AM. Is liver biopsy useful in the evaluation of patients with chronically elevated liver enzymes? Ann Intern Med 1989;111:473-8.

36. Kundrotas LW, Clement DJ. Serum alanine aminotransferase (ALT) elevation in asymptomatic US Air Force basic trainee blood donors. Dig Dis Sci 1993;38:2145-50.

37. de Franchis R, Meucci G, Vecchi M, et al. The natural history of asymptomatic hepatitis B surface antigen carriers. Ann Intern Med 1993;118:191-4.

38. Lok AS, Ghany MG, Watson G, Ayola B. Predictive value of aminotransferase and hepatitis B virus DNA levels on response to interferon therapy for chronic hepatitis B. J Viral Hepat 1998;5:171-8.

39. Lai CL, Chien RN, Leung NW, et al. A one-year trial of lamivudine for chronic hepatitis B. N Engl J Med 1998;339:61-8. 